University of Warwick institutional repository: http://go.warwick.ac.uk/wrap This paper is made available online in accordance with publisher policies. Please scroll down to view the document itself. Please refer to the repository record for this item and our policy information available from the repository home page for further information.

To see the final version of this paper please visit the publisher's website. Access to the published version may require a subscription.

Author(s): Ben Clift; Jim Tomlinson

Article Title: Fiscal policy and capital mobility: the construction of economic policy rectitude in Britain and France

Year of publication: 2004

Link to published version:

http://dx.doi.org/10.1080/1356346042000311155

Publisher statement: None 


\title{
Fiscal Policy and Capital Mobility: The Construction of Economic Policy Rectitude in Britain and France
}

\author{
Ben Clift (B.M.Clift@Warwick.ac.uk) and Jim Tomlinson \\ (J.D.Tomlinson@Dundee.ac.uk)
}

New Political Economy Volume 9, Number 4 (2004), pp. 515-537. ISSN 1356-3467 print; ISSN 1469-9923 online.

\section{Introduction}

It is a commonplace of both political and academic argument that the last quarter of twentieth century saw major diminution of national economic policy autonomy, with increased capital mobility identified as the key explanatory variable. ${ }^{1}$ Schor talks of the 'Rise and fall of the national model', ${ }^{2}$ and many concur, identifying a decline of the doctrines of 'Keynesianism' as synonymous with this declining national capacity. $^{3}$ Thus, for example, Tony Blair noted in his 1995 Mais lecture; 'We must recognise that the UK is situated in the middle of an active global market for capital a market which is less subject to regulation today than for decades. An expansionary fiscal or monetary policy that is at odds with other economies in Europe will not be sustainable for very long. To that extent the room for manoeuvre of any government in Britain is already heavily circumscribed'. ${ }^{4}$

Responding to these widespread ideas about the constraints on national economic policy, Cohen identifies the key research agenda to which this article contributes;

The interesting question ... is not whether financial globalization imposes a constraint on sovereign states; it most clearly does. Rather, we should now be asking how the discipline works and under what conditions. What accounts for the remaining room for manoeuvre, and why do some countries still enjoy more policy autonomy than others? ... It is time to move beyond broad generalizations about the logic of the unholy trinity [see below] to more disaggregated analysis of the complex linkages between global finance and domestic performance. ${ }^{5}$ 
The existing literature offers some qualification regarding the strength of the constraint along two main lines. Firstly, empirical evidence shows that welfare states show no general cutbacks since the sharp increase in capital mobility, only an end of expansion. ${ }^{6}$ Secondly, Mosley ${ }^{7}$ identifies a narrow focus of financial markets on few macro aggregates in advanced capitalist democracies, notably the rate of inflation, deficit and debt ratio, in determining government credibility. This focuses our attention on the construction of financial credibility as a key issue in determining the degree and nature of enduring policy autonomy (or conversely the constraints thereon). This in turn draws our gaze to the institutional and ideational context in which 'credibility' is constructed, and the crucial role of a number of agencies. ${ }^{8}$

Despite such qualification regarding capital mobility impact, the idea of 1970s as a watershed for national policy autonomy is still pervasive. ${ }^{9}$ This article looks at how that credibility is constructed in the contemporary period (1997-2003), and goes on to analyse the degree of enduring fiscal policy autonomy in two cases - Britain and France. ${ }^{10}$ Our selection of the UK and French cases brings to the fore these clear examples of national policy autonomy, and illustrates the different policy autonomy implications of choosing fixed or floating exchange rates.

The article is divided into three sections. The first sets out, and critiques, the prevailing orthodoxy regarding capital mobility and economic policy autonomy, namely the 'strong' version of the of the capital mobility hypothesis (CMH). The second establishes the ideational and institutional context within which financial credibility is constructed with reference to the International Monetary Funds (IMF), bond-rating agencies, and the Euro and the Stability and Growth Pact (SGP). The third section explores fiscal policymaking autonomy, and the constraints thereupon, in the context of increased capital mobility, in Britain and France since the early 1990s.

\section{The Changing International Political Economy and National Policy Autonomy}

The scale, instability, and speed of capital flows increased markedly since the collapse of the Bretton Woods system in the 1970s (see below). This is not to say that capital mobility was not a prevalent feature of the international political economy under Bretton Woods, ${ }^{11}$ rather that the scale and nature of mobility has increased very 
significantly since the 1970s. In the contemporary international political economic context, 'world-wide trading of currencies and government bonds means that exchange rates and interest rates, the two critical variables in the formulation of national macroeconomic policy, are determined in the context of global financial markets. 12

Credibility with financial markets has become an inescapable priority for macroeconomic policymakers. ${ }^{13}$ Governments became increasingly convinced of the merits of 'stability', or low and stable rates of inflation and fiscal discipline, adopting restrictive monetary policies in order to avoid incurring a 'risk premium' imposed on borrowing by investors suspicious of potentially inflationary macro-economic stances. ${ }^{14}$ Capital mobility and financial deregulation changed the cost/benefit analysis of macroeconomic strategies. Yet, whilst it is undoubtedly the case that the power balance has shifted in favour of private capital holders, such a disparate and diverse group of actors do not 'impose' a policy agenda on states.

There was, it should be recalled, more than one route to credibility. Many neo-liberal opinion formers strongly favoured floating rather than fixed exchange rates because they explicitly rejected the Keynesian Welfare State model that the fixed rate regime of embedded liberalism permitted. An alternative, 'Ordo-liberal' path to credibility could be pursued in the European context, by pegging to the Deutschmark and 'importing' German credibility - often initially at the cost of high interest rate premia, and deflationary fiscal policies. ${ }^{15}$

\section{The 'Capital Mobility Hypothesis'}

The Capital Mobility Hypothesis posits (and, we argue, overstates) a powerful constraining effect of financial capital mobility upon macroeconomic policy. ${ }^{16}$ Cohen's 'unholy trinity' identifies the intrinsic incompatibility of exchange-rate stability, capital mobility, and national policy autonomy. ${ }^{17}$ With relation to exchange rates, one choice facing policymakers is, fixed or floating? Under fixed exchange rates, capital mobility increases the efficacy of fiscal policy but eliminates monetary policy autonomy, whilst under floating rates, capital mobility renders fiscal policy ineffective, but monetary policy can be set independently. ${ }^{18}$ 
Increasing financial liberalization and deregulation have facilitated capital mobility, structurally empowering investors (and particularly large financial institutions) vis-àvis governments. ${ }^{19}$ These empowered actors, Oatley argues 'prefer low inflation and balanced budgets and rapidly shift their funds in response to macroeconomic policies that threaten to generate inflation or otherwise reduce the return on investment relative to other national markets'. ${ }^{20}$ The 'stringent logic' of the 'unholy trinity' imposes, according to Cohen 'an increasingly stark trade-off on policymakers,21 which allegedly leads governments to eschew expansionary fiscal and monetary policies in favour of tight money and balanced budgets.

With regard to capital mobility, one putative policy choice is whether or not to employ capital controls. Yet in the wake of removal of all capital controls across the EU in 1990, resorting to capital controls seems an unlikely (and probably ineffective) policy scenario. $^{22}$ Thus our analysis explores, in the absence of the re-imposition of capital controls, how much policy autonomy governments retain in the contemporary period. $^{23}$

As noted above, empirical evidence, ${ }^{24}$ addressing both the 1980 s and the 1990 s, suggests that the fiscal 'wiggle room' or policy space is considerably greater than the stark logic of the unholy trinity suggests. The reason the Hypothesis and Trinity may be not wrong but overstated relates to the causal mechanisms by which such complex processes impact on, or rather interact with states and state actors. The logic of the 'Trinity' is rooted in a 'textbook' perfectly integrated open international economy. There is evidence that short-term markets exhibit a high degree of integration. ${ }^{25}$ That said, Epstein \& Gintis, ${ }^{26}$ Feldstein \& Horioka, ${ }^{27}$ Epstein, ${ }^{28}$ and Watson ${ }^{29}$ all point to home bias and limits of flows measured, and lack of profit equalization between markets. To the extent that the real conditions that obtain in international financial markets diverge from the textbook caricature, we may expect limitations on the operation of the constraints the Capital Mobility Hypothesis posits.

Our approach to capital mobility, and its impact on national policy autonomy, takes methodological issue with the dominant strand of IPE analysis, which Sinclair terms the ‘structural approach' to international capital mobility, rooted in 'state-centric 
ontology of neorealism'. ${ }^{30}$ These scholars see international capital mobility as purely exogenous constraint on states conceived as unitary actors with fixed preferences. ${ }^{31}$ Sinclair argues convincingly that 'Linear structural models of cause and effect between ICM and the state are ... likely to be inadequate understandings of what is really a reciprocal or dialectical process. ${ }^{32}$

Our analysis involves a number of departures from the 'structural approach'. Firstly, it is important to disaggregate beyond the level of the state. The changing international economic context has, Dyson convincingly argues, structurally empowered particular groups and constituencies within state elites, notably central bankers and finance ministries. ${ }^{33}$ For example, one reason why EMU in Elie Cohen's term, set in marble the strategy of competitive disinflation, ${ }^{34}$ was that it bore the imprint the 'conservative liberal' French financial elite of the Trésor and the Banque de France, empowered within the French state by the EMS, and then the ERM. ${ }^{35}$

Secondly, attention must be paid to this institutional and ideological context within which the constraint it imposes on states is constructed. The role of key international institutions (such as Bond Rating Agencies and the IMF) needs to be addressed in shaping the preferences and understandings of economic rectitude that prevail within the international political economy.

Thirdly, the ideational level must be afforded due weight in analysis. Structuralist and exclusively material accounts miss the role of ideational factors in shaping economic policy rectitude, neglecting what Dyson has termed 'the underlying importance of ideas as real phenomena and of their internalisation by domestic elites ...[which] ... underlines the complex interweaving and mutual interdependence between the material and the ideational. ${ }^{, 36}$ As Keynes pointed out in an early constructivist approach to financial credibility in financial markets, with his beauty contest analogy, markets are often less interested in the economic fundamentals than in other actors' (not necessarily exhaustively well informed) perceptions. Focusing on this ideational level requires taking account of the interaction of agency and structure. Structuralist accounts within the CMH framework neglect the role of agency of governments, Treasuries, and financial elites within the core executive in the process of the construction of economic rectitude (demonstrated in the empirical sections below). 
The mobility of different forms of financial capital has different implications for policy autonomy. For example, Mosley's analysis of the policy consequences of deregulated bond markets has unearthed that, as far as developed economies are concerned, only specific indicators are of interest to key market actors, leaving extensive latitude to governments in how they deliver on these indictors, and furthermore to pursue policies which do not adversely effect the key indicators. ${ }^{37}$ Inflation is a pressing concern, and to a lesser extent budget deficits, although 'the influence of financial markets on government policy is much stronger on the monetary policy side than on the fiscal policy side'. ${ }^{38}$ Little else is affording significant attention, and quantitative analysis unearthed a surprisingly small impact on risk premia of sizeable shifts in budget balance. ${ }^{39}$

\section{The Contemporary IPE and The Institutional Context of Policy Autonomy}

This more fine-grained analysis of how capital mobility operates, its interaction with states and domestic policy actors, and what institutions shape its impact, is necessary to unearth how financial credibility is constructed. The following sections briefly establish key elements of the ideational and institutional context within which fiscal policy rectitude is constructed for advanced economies.

\section{The IMF}

In the period between the foundation of the IMF and the breakdown of the fixed exchange rate system in the early 1970s, the financial credibility of national governments was closely tied to the role of the IMF. As scale of private lending activity increased, and the role of private credit-creating bodies has expanded, ${ }^{40}$ this has become much less true. The IMF continues to perform the surveillance function laid down in the 1978 rewriting of Article IV of its Articles of Agreement, gathering large amounts of data and regularly publishing its opinion of the economic policy rectitude of governments. This remains a significant contributory factor to the intellectual climate of opinion, but in the absence of the leverage it enjoyed as a lender, IMF influence on economic policymaking within advanced capitalist democracies is greatly reduced. 
The economic context of the climate of opinion has seen some quite dramatic shifts in very recent times. For the last three decades of the twentieth century fears of inflation dominated financial markets and much government economic thinking. Such fears formed a crucial element of the context in which economic policy was discussed.

By 2002 concerns about deflation, especially in Japan and China, led to the setting-up of an IMF task force. ${ }^{41}$ This stressed the conjunction of declines in global equity markets, excess capacity in many industries, slow economic recovery, geopolitical uncertainties and higher oil prices as evidence of how deflationary pressures might emerge. Whilst noting that the danger of a global deflation was small, nevertheless, the IMF warned of the potential difficulties of a falling price level, the need to prevent any such deflation before it occurred, and the desirability of constructing unorthodox policy responses if the threat strengthened. Although the deflationary threat has abated, very low inflation itself involves a strikingly different economic environment from that prevailing since the 1970s, not least because of the associated very low interest rates. Such rates mean that government debt burdens are much reduced, and worries about fiscal unsustainability, so prevalent up to the 1990s, no longer look plausible. In turn, much of the edifice set up to constrain fiscal 'irresponsibility' of national governments seems anachronistic. This highlights the contingency and context-specificity of financial credibility which is much underplayed in many accounts focusing on neo-liberal policy constraints 'imposed' by financial markets. ${ }^{42}$

\section{Bond Rating Agencies}

In the wake of the internationalisation of capital markets in the contemporary period, as the scale of private lending activity increased, ${ }^{43}$ the views of the major bond rating agencies, Moody's and Standard \& Poors, on the creditworthiness of governments became much more significant as capital markets grew more important as sources of financing relative to traditional bank loans. ${ }^{44}$ These agencies, in rating sovereign bonds, became an important indicator of the credibility of government economic policies, and play a key role in inducing confidence regarding borrowing governments in these disintermediated international capital markets. 
The apparent objective, scientific nature of the rating process is spurious. Analysis is both quantitative and qualitative, and is bound up with prior assumptions about economic rectitude, and thus involves value judgements. A particular paradigm, strongly influenced by new classical macroeconomics and the political economy of the neo-liberal New Right, prevails. The bond rating agencies peculiarly influential position within the international political economy has contributed to the dissemination of this world view and its emergence as a policy orthodoxy. Sinclair situates this ratings process within a wider 'construction' of 'deficit discourse' involving particular notions of fiscal rectitude. ${ }^{45}$

No doubt partly because of the low inflation and low interest rate international political economic context, the shifts in the relative importance of actors involved in the construction of rectitude does not appear to have reduced policy autonomy. These institutions have not been a source of fiscal policy constraint in the late 1990s and early 2000s. Whatever these agencies misgivings about fiscal prudence in UK and France, they have deemed both governments as wholly creditworthy throughout the period under discussion here, with Moody’s assigning both country’s long term sovereign bonds a rating AAA since the early 1990 s. $^{46}$

\section{The Institutions of European Economic and Monetary Integration.}

Of primary importance in shaping credibility in the contemporary European context is the process of European monetary integration, and the political economic paradigm which has underpinned it. ${ }^{47}$ As noted above, a particular set of core executive elites of the key countries (notably central bankers and finance ministry technocrats) were structurally empowered in the process of constructing EMU. ${ }^{48}$ The imprint of this empowering of technocrats in finance ministries and central banks can clearly be seen in the neo-liberal sound money and finance orthodoxy that shaped the paradigm within which EMU was conceived, developed, and implemented. The influence of this particular political economic paradigm also ‘fed through' into governments' credibility bolstering fiscal policy-making rule-making, firstly in the Maastricht convergence criteria, and subsequently the Stability and Growth Pact (SGP). 
This illustrates the interaction between capital markets and state actors. The relationship between policy elites, the institutional parameters noted above and financial market actors engaged in the construction of economic rectitude is a complex and reciprocal one. Mosley notes that the Maastricht criteria became widely used by global bond market participants as a metric of financial credibility. Financial elites within the core executives of the EMU participating countries were thus engaged in the construction of the yardsticks by which their fiscal rectitude would be judged, notably by specifying an 'appropriate' level of deficit at 3 per cent. ${ }^{49}$

As Dyson notes, 'EMU involves powerful changes to material realities ... the form and impact of these effects is also shaped by ideas and their discursive construction'. ${ }^{50}$ In this sense, states, and state actors, and their interactions with financial markets, were constitutive of financial market policy constraints.

Significantly, 'governments that adhered to the rules quickly gained credibility with financial markets'. ${ }^{51}$ Thus advanced industrial economies are judged in global bond markets by a narrow set of rules, which, under certain conditions, governments are able to set. $^{52}$

\section{Financial Credibility and the Stability and Growth Pact}

For members of the Eurozone the SGP involves legally enforceable constraints on fiscal policies, which largely supplant the constraints maintained by financial markets and international financial organisations in the previous decades. The very existence of the SGP reflects worries that within monetary union individual national governments would face looser constraints, potentially leading to spillover effects from national policies to the wider Eurozone. ${ }^{53}$ How far this has a significant impact on national governments depends both on the rules of the SGP and the extent to which governments are persuaded/coerced into compliance.

To limit 'bad behaviour' by national governments the EU pursued a number of policies. One was to legislate a 'no bail-out' rule, so that financial institutions lending to individual governments would not be misled into believing that such lending would be guaranteed by the Union as a whole. Second, there are limits on bank holding of government debt to prevent excessive monetising of the debt and the risk that 
excessive borrowing could threaten the stability of financial institutions. ${ }^{54}$ Finally, there is the SGP with its rules about the fiscal policies of individual governments, backed by sanctions. ${ }^{55}$ The SGP, agreed after fraught political negotiation, reflected the German-led insistence on a tough regime, so that in addition to a re-assertion of the 3 per cent and 60 per cent ceilings, a medium-term aim of a budget 'close to balance or in surplus' was inserted. As part of the Pact governments have to submit an annual stability programme. Only in exceptional circumstances (defined in terms of depth of a recession) will deficits be allowed to exceed 3 per cent.

Deficits fell most sharply in the run-up to 1999, and signalled the political commitment of governments to accept the very rough and ready targets of the Maastricht Treaty and the SGP and bear this cost of the Euro. The recent arguments about the crudity of the SGP should not blind us to the fact that fiscal discipline was asserted very successfully in the 1990s, and in that context current differences appear so far at least quite marginal. ${ }^{56}$

While almost all commentators have accepted the need for fiscal discipline, some questioned the desirability of any rules at all, while others questioned the particular rules applied. Although Article 104 of the Maastricht Treaty specified analysis of the role of public investment within the deficit, and the taking into account of the economic cycle, and the medium term budgetary position, these precisions have been largely forgotten. ${ }^{57}$ The crude deficit rule made no allowance for the state of the economic cycle, nor the fact that most countries started with significant structural deficits (i.e. deficits not caused by the cycle). The debt rule did not address under what conditions debt becomes unsustainable. ${ }^{58}$ In fact the deficit rule would not be very restrictive in the medium term if we make a simple comparison with long-run fiscal policy. ${ }^{59}$ Only rarely have governments run deficits of more than 3 per centsuggesting such a rule does not involve a tightening of rules enforced by previous institutional arrangements, though changing underlying conditions make such comparisons complex. ${ }^{60}$ Had the Euro had been launched at a time when structural budgets were in balance, or had a period of faster growth preceded the 2002 slowdown, the 3 per cent rule would probably not have caused difficulties. 
Slow growth of the Euro area since 2001, exacerbated by the slow response of the ECB to the slowdown, forced fiscal policy into a more expansionary form. ${ }^{61}$ The ECB's policy record has been unaccommodating, and betrays its excessively inflation-oriented agenda, reflecting the sound money and finance agenda instilled in the foundations and architecture of EMU, ${ }^{62}$ despite the brief emergence of deflationary fears detailed above. ${ }^{63}$ In 2002 warnings were issued to Germany and Portugal, and later France about excessive deficits. This created a political crisis for the EU, not least because of the founding assumption of the SGP that the Germans would be the model of fiscal rectitude. ${ }^{64}$

This narrative about the SGP emphasizes how contingent on political and economic circumstances its terms have been. More significantly, it does not seem that SGP has made any major difference to the capacity of national governments to conduct their own fiscal policies. Analysing budgetary policy pursued in the Eurozone period 19972002, Mathieu \& Sterdyniak conclude that the Commission’s infrastructure for enforcing the SGP 'seems to have had almost no impact on national policies' ${ }^{65}$ Contrary to Commission desire for balance, the structural budget deficit (not including debt servicing costs) grew by 1.2 per cent of GDP between 1997 and 2002. The Eurozone public deficit in 2002 was 2.3 per cent (not the 0.3 per cent of the 2001 Stability Plan). No fewer than Nine Euro countries are set to miss the 2004 target for budgetary equilibrium, despite the Commission's exhortations.

\section{French Fiscal policy}

Increasing financial liberalization and deregulation facilitating capital mobility allegedly leads Governments to eschew expansionary fiscal and monetary policies in favour of tight money and balanced budgets. ${ }^{66}$ Yet the degree of constraint and starkness of policy trade-offs posited by CMH scholarship outlined above are difficult to reconcile with the recent history of French fiscal policymaking.

In the early 1990s, as recession took hold, Bérégovoy’s Government pursued a bold, countercyclical, expansionary fiscal policy in 1992, justified in Keynesian terms of the need to counter the demand squeeze. This must also be situated in its appropriate electoral context. The Socialist Government was trying, unsuccessfully, to stave of a 
crushing defeat, punishment for its having overseen inexorably rising unemployment, and a growth in inequality, in the post-1983 U-turn period. ${ }^{67}$

This countercyclical fiscal stimulus, in combination with a deepening recession, led to a decisive breaching of the Maastricht 3 per cent public deficit criteria. Peaking at 5.6 per cent in 1993, France remained in breach until $1998 .{ }^{68}$ As slow growth, compounded by the need to steer a path consistent with the Maastricht convergence criteria continued to exert pressure on the public finances, fiscal policy became more restrictive. The public deficit was progressively reduced, between 1995 and 1997 as the 3 per cent reference value for the budget deficit became a key policy concern. Austerity measures and fiscal tightening brought the deficit down, according to official figures, to 3.1 per cent in $1997 .^{69}$

Meeting, or just missing (depending on which figures you trust), the 3 per cent reference target in time for accession to EMU involved some creative accounting. This illustrates the socially mediated nature of economic credibility, and the role that states, and in particular Finance Ministries, can play in constructing their own fiscal rectitude. The French state agreed to take over the future pension obligations of France Télécom's in return for a payment of 45 billion francs to the French state. ${ }^{70}$ This enabled the French state to massage downwards its public deficit figure, bolstering perceptions of soundness whilst not improving the 'economic fundamentals' upon which those perceptions were supposedly based.

French public finances subsequently improved considerably in no small part as a result of the economic upswing between 1997 and 2000. The extent to which French fiscal policy was directed at the Jospin Government's employment and redistributive priorities illustrates the existence of the room to manoeuvre. Targeted redistributive measures gave an expansionary boost to purchasing power in the French economy. From 1999 onwards, public spending accelerated and budgets became more redistributive. ${ }^{71}$ This, combined with redistribution to lower income brackets with a higher propensity to spend, kept demand buoyant during the growth period. Purchasing power as a proportion of household revenue increased by 16 per cent between 1997 and 2002 (the largest 5 year increase in over 20 years). ${ }^{72}$ There has been continuity in the role and importance of automatic stabilizers within the French 
fiscal policy framework, though both the recession of the early 1990s, and the downturn which followed a decade later.

The considerable degree of policy autonomy in both decisions appears considerable and gives the lie to the supposed tight constraints in the context of capital mobility. Indeed, the critique of the SGP that it takes no account of the economic cycle is double-edged. Some point to a lack of symmetry in the SGP arrangements which leave governments excessively unconstrained during economic upswings. ${ }^{73}$ In 2000 , the Jospin government embarked on the biggest tax cut in 20 years. ${ }^{74}$ Given the subsequent worsening of the economic climate and the public finances between 2001 and 2003, many retrospectively criticised the Jospin government for being excessively profligate with its cagnotte (tax windfall), using it to cut taxes rather than repay more debt.

The Jospin Government reduced its debt burden due to lower interest rates, not debt reduction. Indeed, debt levels were rising in this period. In the last decade, although dipping as a result of the upswing just below 57 per cent of GDP in 2001, French public debt has increased substantially, with Government forecasts predicting 65.6 per cent of GDP for $2005 .^{75}$ Although a considerable burden, the costs of debt would have been more punitive in the absence of EMU, with investor confidence in the advent of the Euro reducing interest rate risk premia in the mid-to-late 1990s. ${ }^{76}$ Further 'wiggle room' was afforded by the specific context of the restructuring of French capitalism in the late 1990s and early 2000s. ${ }^{77}$ Given the draw on the public purse of debt servicing, (attempted) deficit reduction, and tax cuts, receipts from the Government's privatisations programme provided a valuable source of income - (50 billion francs per year between 1997 and 1999), which also helped contribute to social spending priorities.

Room to manoeuvre is further provided by the role governments and Finance ministries play in constructing the narrative of their own fiscal rectitude. Specifically, they are able to exploit the inherent inaccuracy of economic forecasting to present deficit reduction forecasts, and prognoses of future debt levels, in an unrealistically positive light. This further illustrates the role that states and Finance Ministries play in constructing their own economic rectitude, and perceptions thereof. The SGP- 
stipulated Stability Plans explain how, over four years, the public deficit will approach equilibrium. Even annual forecasts are always inaccurate, given this time horizon, governments are tempted to make over-optimistic growth predictions (since under-optimistic ones are equally flawed), which would, in a relatively painless way, deliver the budget balance.

French policymakers, it seems, value the room to manoeuvre that can be gained from the role they play in the construction of perceptions of their economic rectitude. This is amply demonstrated in the French stability plan for 2005 to $2007 .^{78}$ All forecasting is based on two predicted growth levels (2.5 per cent and 3 per cent), the former, characterised as 'prudent' in the document, is still rather optimistic. ${ }^{79}$ These documents play a legitimising role, containing solemn, if often vague pledges prudence and belt tightening, whilst retaining planned tax cuts. French budgetary policy in 2003 was less restrictive than their stability plan, ${ }^{80}$ and this is by no means an exception. These are an exercise in reframing perceptions to legitimise government policy, speaking the language of fiscal austerity, whilst using the opportunity to create more room to manoeuvre.

If and when real growth parts from the optimistic prediction, do governments engage in restrictive budgetary policy and further stifle weak growth? Or do they allow the Budget deficit to grow? Evidence from France between 2001 and 2004 suggests the latter is at least as viable an option as the former without incurring punishment from financial markets. Despite Commission rebukes of excessively expansionary fiscal policy, and reaffirmations of the 3 per cent rule, ${ }^{81}$ France's September 2002 SGP stability plan, and Budget plans for 2003 (based on extremely optimistic growth forecasts), did not conform to the budget balance requirements by 2004, nor even by 2006. ${ }^{82}$ France thus remained an 'unrepentant sinner' ${ }^{83}$

Perceived absence of tight constraint becomes most evident at crucial moments in the electoral cycle. No doubt as a result of the electoral cycle, in 2002, budgetary policies were sharply expansionary, as spending increased by almost 3 per cent in volume, and taxes were significantly reduced. ${ }^{84}$ The more expansionary fiscal policy pursued in France, and its impact on internal demand, in part explains the hitherto superior 
growth performance of France compared to the Eurozone as a whole -in both upswing and downswing phases.

Whilst on the spending side, the electoral cycle doubtless provided some impetus for the expansion, its impact has been still more dramatic on the receipts side. Many saw the Jospin Government's tax cuts outlined above as an electoralist stunt, driven at least in part by a partially populist logic, given the 'war chest' provided by economic growth, and the proximity of decisive elections. ${ }^{85}$ Yet this example pales into insignificance when compared to the tax promises made by Chirac, in a considerably worse economic climate, in the context of the 2002 elections. A centre-piece of Chirac's campaign was a 5 percent income tax reduction pledge. The rhetoric of Chirac's campaign emphasised expansionary domestic policies, and chose to draw a veil over European constraints that these policies blatantly flouted (an approach which had served him well in his 1995 presidential campaign).

Excessively optimistic (3 per cent growth) forecasting allowed Chirac to promise the reduction of income taxes by a third by 2007. This was also the date by which he pledged domestically to achieve budget balance (in March 2002, Chirac was still telling the Commission and European partners that balance would be achieved in 2004). Unsurprisingly, Chirac and the Raffarin Government called for a 'softening' of the SGP in the summer of 2003, yet Government did not abandon plans of a 3 per cent income tax cut. ${ }^{86}$ A combative Commission initiated Excessive Deficit Procedures against France in May 2003.

The 'freezing' of the Excessive Deficit Procedures, against the wishes of the Commission and a number of Euro member countries, in the wake of the Ecofin meeting of November $24^{\text {th }}-25^{\text {th }}$ provoked an open crisis of the SGP. Interestingly, the impact on the financial markets of this open crisis of the institutional framework of EMU, which the newly appointed governor of the ECB, Jean-Claude Trichet warned was a grave danger for the credibility of the Euro, was negligeable. Indeed, the collapse of SGP coincided with the highest ever value of Euro to dollar, at the end of a 16 per cent appreciation in 2003. Indicating actors on financial markets continue to have confidence, long term interest rates. Long-term French sovereign bond rates rose 
slightly from 4.33 to $4.44^{87}$ - but this was simply a fluctuation, and there is no indication of any discernable effect on costs of borrowing. ${ }^{88}$

Contradicting Pedro Solbes, Finance Minister Francis Mer insisted that the 'spirit of the Pact' was still being respected, ${ }^{89}$ and in this he has some justification - notably the pledge to reduce deficits below 3 per cent by 2005 (in September 2003, French officials had been angling for 2006). That said, French Government predictions of a 2.9 per cent deficit in 2005 were again based on optimistic growth forecasts, ${ }^{90}$ more sober forecasters put the likely figure at 3.4 per cent. $^{91}$

French economic policymakers attitudes to European constraint appear schizophrenic. The 2003 budget explicitly rejected the Commission's target of budget balance by 2004, and indeed 2006. ${ }^{92}$ Its budget for 2004 contained further tax cut promises which, once again, flouted commitments made to European Partners (this time at the Stresa Econfin meeting) that the deficit would be brought below 3 per cent by 2005. That said, the shift to a more restrictive path (a shift further emphasised in the wake of European disputes in late 2003), was in part a reflection of a concern to keep within striking distance of SGP reference points.

France's more austerity-oriented fiscal policies in 2003 and 2004 (including increased social charges to more than offset tax cuts, and plans to cut certain social programmes, notably health insurance), in the context of weak growth, risks establishing vicious circle whereby, the more growth is dampened down by restrictive budgetary polices, the more austerity will be needed to tackle the public deficit and try and rein it in under 3 per cent. ${ }^{93}$ A recent IMF report endorsed this view, warning against 'rigid adherence to annual deficit targets [which] can impart a procyclical bias to fiscal policy through contractionary measures to buttress revenues in a downswing', and has argued that binding rules which 'allow cyclical revenue fluctuations to be reflected in annual outcomes for the budget balance ... would not sacrifice — and perhaps it would even enhance_-policy credibility. ${ }^{94}$ The IMF raise long term concerns about fiscal sustainability with relation to pension and health policy reform in particular, but in the short term are content to endorse the 'full play being given to automatic fiscal stabilizers' in contributing to recovery. ${ }^{95}$ 
Ironically, although conditions should permit a return to growth around 3 per cent in 2004-5, which would enable France to meet its commitments undertaken at Ecofin in November 2003, the likely fly in the ointment is a more restrictive budgetary stance since 2003 dampening demand and consumption, hampering growth. Despite government predictions of a 3.6 per cent deficit in 2004, other estimates put the figure at between 3.9 per cent and 4.2 per cent as a result of weaker growth. ${ }^{96}$

\section{British fiscal policy}

Britain was ahead of France in the pace of financial liberalization, with exchange controls abolished in 1979 and the opening up of the City of London to much greater competition in the 1980s. Yet despite substantial institutional and political differences between the two countries, the same broad theme may be repeated: despite this liberalization the British authorities have been able to maintain a substantial degree of fiscal policy autonomy.

The debacle of Britain's exit from the ERM in 1992 was followed by an attempt to establish a new monetary regime by the specification of an inflation target (2.5 per cent) and the creation of much greater transparency in the conduct of monetary policy. This latter involved the introduction of a regular Inflation Report spelling out the basis of policy monetary judgements and the use of 'seven wise men ' to give independent policy advice. ${ }^{97}$ This attempt to reconstruct monetary credibility initially went along with extraordinarily large fiscal deficits. From surpluses in the fiscal years 1988/9 and 1989/90, the recession of the early 1990s saw deficits in both 1992/3 and 1993/4 of 7.8 per cent of GDP-higher even than the alleged 'annus horribilis' of 1975/6 when the figure was 7.1 per cent. ${ }^{98}$ Unlike in 1975/6, however, these deficits did not have disastrous effects on confidence. The initial departure from the ERM saw a substantial fall in the exchange rate, but this then stabilised until the end of 1994, to be followed by a 6 per cent fall between January and April 1995. Similarly, widening differentials in interest rates with the US and West Germany only appeared from 1994. ${ }^{99}$ Hence through the peak of the deficits the government was not under great pressure for their reduction. Partly this was because from 1993 the government was imposing very large tax increases to try and get the deficit down; indeed, the two budgets of 1993 together imposed the biggest ever peacetime tax hikes in British history. But perhaps most important was the fact that inflation 
remained strikingly low in the early 1990s; at its lowest point it was under 2 per cent in 1993. ${ }^{100}$ Also of help was the fact that the debt/GDP ratio, though rising, was well inside the Maastricht 60 per cent figure, running between $40-50$ per cent at its peak.

The Conservative government of the mid-1990s had a proclaimed objective to eliminate public borrowing entirely, though in fact it remained in deficit until it lost office in 1997. However, there was a notable fiscal tightening in the mid-1990s, so that even allowing for the economic recovery, the fall in the PSBR was very sharp, to 1.2 per cent of GDP in 1997/8. ${ }^{101}$

These policies have of course been conducted against the background of a floating exchange rate since the ERM debacle of 1992. Under the Conservatives the Maastricht fiscal criteria were officially deployed as benchmarks for policy, but without any commitment to the idea that this was paving the way for Britain to enter the projected single currency. By contrast, the Labour government elected in 1997 committed itself 'in principle' to Euro membership, but in practice this remained a distant prospect. Though Britain is therefore not a signatory to the SGP, Labour's commitment to eventual Euro entry has led to a clear statement of adherence to the principles of the Pact, and its use as one, though by no means the only, benchmark in discussions of UK fiscal policy. ${ }^{102}$

A major reason for continuing British wariness about Euro entry was the buoyancy of the British economy through the 1990s, with a long upswing in activity after 1992, with only minor interruptions at the end of the 1990s. This upswing, as noted above, allowed a sharp reduction in fiscal deficits from the mid-1990s, albeit in combination with tight controls over expenditure.

Initially these tight controls were maintained by the Blair government, one consequence of the re-assessment Labour's macroeconomic policies had been subject to in the long years in opposition between 1979 and 1997. The broad thinking behind New Labour's approach was spelt out succinctly by a key adviser in Labour's Treasury team. ${ }^{103}$ At the core of his argument was the belief that 'credibility is the elusive elixir of modern macroeconomics', a belief founded not only on developments in economic theory in the 1980s and 1990s, but also on the manifest failure of the previous Labour government to maintain such credibility in the mid 1970s. Bringing together structural and political elements, Balls argued that: 'The rapid globalization of the world economy has made achieving credibility rather more than less important, particularly for an incoming left-of centre government which has been out of power 
for two decades'. ${ }^{104}$ Ruling out what was seen as the previous errors of fixed and intermediate policy rules (e.g money supply or exchange rate targets), Balls argued that what was needed was 'stability through constrained discretion'. In practice this meant a strategy of establishing a track record on stability which would, after a period, give the government room for short-run manoeuvre.

After its election the Blair government Labour government sought to secure this credibility for its macroeconomic policies by two key policies: granting the Bank of England independence in the conduct of monetary policy, coupled to a commitment to fiscal prudence. Independence for the Bank of England had in fact been discussed in government circles as far back as 1988, when the Conservative Nigel Lawson was Chancellor. ${ }^{105}$ But for a Labour government to grant such independence marked a decisive conversion both to the priority of low inflation as a policy objective and more broadly the logic of credibility as the defining issue. Under the new arrangements a Monetary Policy Committee dominated by the Bank would set interest rates, on the basis of minuted discussions which after a short lag would be in the public domain. The aim of policy would be to achieve the existing target of 2.5 per cent inflation, albeit this would now be 'symmetrical' ie the figure should not be allowed substantially below nor substantially above this figure. ${ }^{106}$

The principles of fiscal prudence were spelt out in 1998, with two key rules enunciated. ${ }^{107}$ The first, the 'golden rule', stated that the government would, over the cycle, borrow only to invest and not to fund current spending. The second, the 'sustainable investment rule', said that public sector net debt as a proportion of GDP would be held stable, and would normally be less than 40 per cent over the cycle.

These rules differed from those of the SGP. The first rule was less restrictive than the SGP's commitment to overall budgetary balance or surplus, in part because of the British backlog of public investment, which had been low since the 1970s and significantly below Eurozone levels at the turn of the century. ${ }^{108}$ The second rule also allowed scope for some expansion of public investment as long as debt did not rise sharply. British debt levels were in any event well below the SGP's 60 per cent maximum, at around 35-40 per cent at the turn of the century depending upon the precise mode of calculation. Finally, the British rules, by emphasising the need for assessment over the cycle, reflected British recognition of the exceptional severity of the recessions of the early 1980s and 1990s, and the consequent desire to let automatic stabilisers do their work. The British rules should not be seen as in any 
simple sense 'slacker' than the SGP, rather it could be said that they reflected a similar commitment to fiscal prudence but in the context of a different national history. This history, contrary to common perceptions, has seen more budget surpluses in the UK than in any other major western economy since $1970{ }^{109}$ - but surpluses seen to have been bought at too high a price in cyclical instability.

In its first period in office after 1997, the Labour government accompanied this prudent fiscal framework with tight limits on public spending growth. However, from 1999, and especially after the second election victory of 2001, the government launched an ambitious spending programme, focused on health, education and infrastructure. The timing of this programme broadly coincided with the deterioration of the international economic environment, hence the characterisation of this period of policy as 'unintended Keynesianism'. ${ }^{110}$ By allowing the deficit to increase the government facilitated a milder slow down in activity than was experienced in most Western economies. This policy was in line with the commitment to allow the automatic stabilizers to be effective.

The combination of rising spending (including financing the invasion of Iraq) and slowing growth brought the government's fiscal 'prudence' under strain in 2003. Where in the run up to the budget of 2002 a current budget deficit of $£ 5.7 \mathrm{bn}$ had been predicted for fiscal 2002/03, the outturn was a deficit of $£ 11.7 \mathrm{bn} .{ }^{111}$ The government argued that over half of this deterioration was due to the workings of the automatic stabilizers, and having generated large surpluses from 1999 onwards, it was still on target to return to surplus in 2005/6 and have a current balance over the cycle. ${ }^{112}$ By the time of the 2004 budget the fiscal balance had further deteriorated, with a deficit in 2003/4 of $£ 37.5 b n$, equivalent to 3.4 per cent of GDP. ${ }^{113}$

The government argues that the projected pattern is still 'consistent with the Government's prudent interpretation of the SGP'. ${ }^{114}$ This is based on forecast data, which suggest that, on the Pact definitions, the budget deficit will have peaked at a cyclically-adjusted 2.3 per cent of GDP in 2003/4, with a small rise in the debt ratio to around 36.5 per cent by 2008/9. ${ }^{115}$ However, some authoritative doubts have been expressed about these projections, not in the current cycle, but the next one. The government's projections, it is argued, depend upon a higher rate of economic growth than is plausible, and therefore tax increases may be required to achieve the fiscal targets. $^{116}$ 
While some members of Ecofin have expressed doubts about UK policy, in general its fiscal rules have been seen as broadly in line with the SGP, but with a recognition of the importance of viewing policy over the cycle. Such assessments of the UK are partly underpinned by the recognition that, unlike several members of the Eurozone, Britain's debt ratio (having fallen from the late 1990s) is even on pessimistic projections likely to rise to levels a long way below the SGP criteria. Indeed, the general point can be made that the SGP criteria are much more of an issue for some members of the Eurozone than for three of the EU non-members (Britain, Denmark and Sweden): 'Trois des meilleurs eleves de l'EU ne sont pas dans le zone euro.... 117

New Labour's macroeconomic policy can be seen as a success in its own terms. As one commentator described the strategy: 'What he (Gordon Brown) really wanted was to be in a position where a Labour Chancellor could comfortably borrow $£ 20$ billion a year for public spending without being accused of profligacy and irresponsibility’. ${ }^{118}$ This has been done with only minor discomfort. While accusations of profligacy have indeed come, as might be expected, from political opponents, they have not come with any seriousness from financial markets. In consequence New Labour has been able to pursue a ‘Keynesian’ policy based on expanding public spending on health and education on a very large scale during an economic slowdown.

Allowing such a deterioration in the fiscal position has been represented as 'a gamble’ by some commentators, ${ }^{119}$ but there is little evidence of loss of credibility. Partly this is because the growth of the economy in 2003 and after has matched the Treasury's forecasts, despite many commentators in 2003 saying these were overoptimistic. In addition, the policies pursued have the broad endorsement of the IMF. The Fund's 2004 country report showed some concern at how far the budget deficit was really as cyclical as the Treasury claimed, and therefore looked for a somewhat faster fall in the deficit in future years. But in broad terms both monetary and fiscal policy were seen as appropriate. ${ }^{120}$

\section{Rules, Credibility, and Policy Space}

Thus in both our cases, in different ways, policy elites have established tough rules to build credibility, then used the policy space so created to pursue policies which might otherwise be unsustainable. New Labour's policies in power have followed the 
prospectus laid out by Balls in 1998: establish tough rules to build credibility, then use the policy space so created to pursue policies which might otherwise be unsustainable. ${ }^{121}$ However it has not all gone entirely to plan. The initial fiscal prudence of 1997-9 proved more difficult to reverse than expected, so that for the whole period 1998-2002 public spending and public investment as a share of GDP were below the levels of the government's Conservative predecessor. ${ }^{122}$ Then, when the big public spending increases did start coming through they coincided with a slowdown in the economy, so that the fiscal balance deteriorated much further than had been anticipated. In response, the government has stuck to its expansionary spending policies, though with substantial slowdowns in the rate of growth proposed for the years after the end of fiscal 2004/5. ${ }^{123}$

In relation to the SGP, (in part as a result of the lesser degree of interpretive flexibility inherent in the original rules) French policymakers have also begun to engage in a degree of revision of those rules, again without any demonstrable adverse effects on credibility. Dyson has characterised the SGP as 'tightened fiscal discipline', 'monitoring of convergence programmes', and 'hard' coordination with sanctions in the background'. ${ }^{124}$ However, after November 2003, this last point requires qualification. This episode also illustrates the enduring relevance of states (and governments within them) as agents in determining the degree of soft-ness or hardness of fiscal policy co-ordination.

The virtues of sound money and sound public finances remain a priority - but they have been set in the context of other priorities, and the potential for conflicts and trade-offs between them has been recognised as has the need to allow the free play of automatic stabilizers, without straitjackets of tight, deficit rules insensitive to the economic cycle, or economic circumstances. Credibility could be retained whilst breaching (for 'sound' economic reasons given the economic conjuncture) the rules. There was nevertheless a desire to retain the rules as reference points and medium term objectives. The shift can be explained with reference to the different ideational and political economic context in which this re-evaluation took place. The harsh fiscal consolidation in the mid 1990s was successful in achieving low interest rates and credibility in the eyes of bond and currency market operators. 
So solid have been the neo-liberal sound money and finance foundations of the EMU project, and the prevalent perceptions arising from them, that French and German governments in particular have been able to attenuate, indeed neglect, budgetary rigour within the policy mix, without any resultant ebbing away of the confidence and credibility (and lower interest rates). Even the shift from 'hard' co-ordination involving fines and penalties, to an altogether 'softer' regime in the wake of the Ecofin agreement to halt excessive deficit procedures against France and Germany, has not as yet demonstrably damaged the credibility of French government bonds with financial markets. ${ }^{125}$ Whilst untrammelled fiscal recidivism would doubtless damage the credibility of the Euro, with impacts on currency and bond markets, clearly the judgement of actors in financial markets suggests that SGP effective collapse, and France enduring (although, more recently, curtailed) 'unrepentant sinner' status has not brought us close to that threshold.

\section{Conclusions}

The CMH depicts a world of deregulated global finance and eroded autonomous fiscal 'policy space'. The empirical evidence drawn from our cases suggests that this view requires significant qualification, and that governments enjoy a good deal more fiscal policy 'wiggle room' than the CMH suggests. Our selection of the UK and French cases has illustrated the experience of both fixed and floating exchange rates. Theoretically, very different kinds of policy autonomy should ensue. Significantly, both cases illustrate substantial degrees of policy autonomy, and offer evidence fiscal wiggle room both within and outside fixed exchange rate regimes, thus confounding the predictions of open economy macroeconomics (assuming perfect capital mobility). These findings are based on just two cases, and the time period under consideration was, for the most part, an economic upswing. This clearly limit the generalisability of findings, but nevertheless the picture which emerges from detailed empirical analysis contrast starkly with the predictions of the Capital Mobility Hypothesis. Our evidence suggests little or no sign of significant budget deficits and expansionary fiscal policies in Britain and France incurring penalties from anxious financial market actors. 
CMH scholarship tends to underplay interaction, and the ways in which a range of international and supranational institutions mediate market forces, as indeed do national political authority structures. The importance of the ideational dimension has also been insisted upon here. Economic rectitude is more politically and economically contingent than the inexorable logic of the unholy trinity suggests. In this deeply political process, actors are able to shape the room to manoeuvre to a considerable degree.

Furthermore, the recent shift to a more restrictive fiscal policy stance in France has not been driven by the inexorable logic of the unholy trinity. If the constraints do bite harder, (and the current and planned French macro policy stance suggest they may), the explanation is to be found in the political and institutional configuration of the Eurozone's institutional infrastructure and rules. Future developments depend much more on the internal politics of the Eurozone and the stand-off between Commission and member states (and more specifically on the reworking of the SGP) than on levels of international capital mobility and changes thereto.

Fiscal policy rectitude is at least in part constructed by actors (notably central bankers and Finance ministries), and not exclusively a tale of exogenous structural constraints (although these constraining material conditions clearly play their part). As a result, these goal posts can shift to some degree. The role of agency of governments, Treasuries, and financial elites within the core executive in the process of the construction of economic rectitude, and shaping the yardsticks by which their credibility levels are judged, has been illustrated with relation to the Maastricht criteria and SGP.

On a broader canvas, British and French Governments' macroeconomic strategies can be seen as powerful illustration of the continuing room for manoeuvre for national governments (even Centre-Left governments) in a world of capital mobility. As always, the size of this room is partly a matter of contingency. The not-whollyexplained continuation of world-wide low inflation has undoubtedly favoured the government's position. But a considerable part of what has occurred must be put down to a well-crafted strategy of recognising the concessions that have to be made to sustain financial credibility, while also seeing that these concessions by no means rule 
out the pursuit of quite traditional social democratic goals of counter-cyclical policy to achieve fuller employment and significantly higher spending on core public services.

What emerges from the preceding analysis is the context dependency of fiscal and economic policy credibility. In the contemporary context of low inflation, and low interest rates, government debt burdens are much reduced. The worries about fiscal unsustainability, so prevalent up to the 1990s, no longer look plausible. In turn, much of the edifice set up to constrain fiscal 'irresponsibility’ of national governments seems anachronistic. Overall, it does not seem that SGP has made a huge difference to the capacity of national governments to conduct their own fiscal policies.

Considerable policy discretion endures, and there is little evidence of government's who exploit this policy space losing credibility with financial market actors and being punished accordingly.

${ }^{1}$ See for example David Andrews, 'Capital Mobility and State Autonomy: Towards a Structural Theory of International monetary relations’ International Studies Quarterly Vol. 38 (1994), pp. 193218.

${ }^{2}$ Juliet Schor, 'Introduction’, in J. Schor and T. Banuri (Eds), Financial Openness and National Autonomy. (Oxford University Press, 1992), pp.4-5.

${ }^{3}$ Egon Matzner and Wolfgang Streeck, Beyond Keynesianism. (Elgar, 1991), pp. 3-4; Anthony Giddens, The Third Way, (Polity, 1998), p. 16.

${ }^{4}$ Financial Times 'Blair sets out framework to cure economic ills: Mais lecture', $23^{\text {rd }}$ May 1995.

${ }^{5}$ Benjamin Cohen, 'Phoenix Arisen: The Resurrection of Global Finance', World Politics, Vol. 48 (January 1996), pp. 283-4.

${ }^{6}$ John M. Hobson, 'Disappearing taxes or the 'race to the middle’? Fiscal policy in the OECD', in L. Weiss (Ed), States in the Global Economy, (Cambridge University Press, 2003); Duane Swank, Global Capital, Political Institutions, and Policy Change in Developed Welfare States, (Cambridge University Press, 2002); Geoffrey

Garrett Partisan Politics in the Global Economy, (Cambridge University Press, 1998) \& 'Global Markets and National Policies: Collision Course or Virtuous Circle?’, 
International Organization, Vol. 52 No. 4 (1998), pp. 787-824.

${ }^{7}$ Layna Mosley, 'Room To Move: International Financial Markets and National Welfare States', International Organisation, Vol. 54, No. 4 (2000), pp. 737-773 \&

Global Capital and National Governments Cambridge University Press, 2003).

${ }^{8}$ Timothy Sinclair, 'Deficit Discourse: the Social Construction of Fiscal Rectitude', in R. Germain (Ed)

Globalisation and Its Critics: Perspectives from Political Economy (Macmillan, 2000), \&

'International Capital Mobility: An Endogenous Approach’ in T. Sinclair \& K. Thomas (Eds) Structure and Agency in International Capital Mobility (Palgrave, 2001), pp. 93-110.

${ }^{9}$ Barry Eichengreen, Globalizing Capital, (Princeton University Press, 1996), Chapter 5.

${ }^{10}$ We put primary emphasis here on fiscal policy partly for space reasons. This article is part of a broader research project, which aims to look at other policy areas in more depth, and also to historicize the account with diachronic comparison with the 1960s. Yet it is also because it is in the area of fiscal policy that many of the bolder claims about eroding policy autonomy are made.

${ }^{11}$ Margaret Garritsen De Vries, The International Monetary Fund, 1966-1971: The System Under Stress (International Monetary Fund, 1976); Susan Strange, International Monetary Relations, (Open University Press, 1976).

${ }^{12}$ David Held, Anthony McGrew, David Goldblatt, \& Jonathon Perraton, Global Transformations, (Polity, 1999), p. 189.

${ }^{13}$ The degree of autonomy under Bretton Woods, however, should not be over-stated. 'Embedded liberalism’ (see John Gerard Ruggie, J. 'International Regimes, Transactions and Change: Embedded Liberalism in the Post-War Economic Order’ International Organization, Vol. 36, No. 2 (1982), pp. 379-415) did not remove the necessity to adjust macroeconomic policy in response to balance of payments deficits or surpluses, as numerous examples demonstrate. Britain and the USA in the 1960s both had to respond to deficits, and Germany to surpluses, albeit the pressures to do so were more muted in the latter case.

${ }^{14}$ Ed Balls, 'Open Macroeconomics in an Open Economy', Scottish Journal of Political Economy, Vol. 45, No. 2 (1998), pp. 113-132.

${ }^{15}$ Ben Clift 'The Changing Political Economy of France: Dirigisme under Duress' in M. Ryner \& A. Cafruny (Eds), A Ruined Fortress? Neo-Liberal Hegemony and Transformation Europe, (Rowman \& 
Littlefield, 2003), pp. 179-183; Magnus Ryner, 'Disciplinary Neoliberalism, Regionalization and the Social Market in German Restructuring' in M. Ryner \& A. Cafruny (Eds), A Ruined Fortress? NeoLiberal Hegemony and Transformation Europe, (Rowman \& Littlefield, 2003), pp. 204-6; Kenneth Dyson, 'The Franco-German Relationship and economic and monetary union: using Europe to 'Bind Leviathan”, West European Politics, Vol. 22, No. 1 (1999), pp. 25-44.

${ }^{16}$ Andrews, ‘Capital Mobility and State Autonomy’, pp. 194-201.

${ }^{17}$ '[I]n an environment of formally or informally pegged rates and effective integration of financial markets, any attempt to pursue independent monetary objectives is almost certain, sooner or later, to result in significant balance of payments disequilibrium, and hence provoke potentially destabilizing flows of speculative capital. To preserve exchange-rate stability, governments will then be compelled to limit either the movement of capital (via restrictions or taxes) or their own policy autonomy (via some form of multilateral surveillance or joint decisionmaking). If they are unwilling or unable to sacrifice either one, then the objective of exchange-rate stability itself may eventually have to be compromised. Over time, except by chance, the three goals cannot be achieved simultaneously.' Benjamin Cohen, 'The Triad and the Unholy Trinity: Lessons for the Pacific Region', in R. Higgott et al (Eds), Pacific Economic Relations in the 1990s: Cooperation or Conflict (Lynne Reiner, 1993), p. 147.

${ }^{18}$ Thomas Oatley, 'How Constraining is Capital mobility? The Partisan Hypothesis in an Open Economy’, American Journal of Political Science, Vol. 43, No. 4 (1999), pp. 1007-9; Paul Krugman \& Maurice Obstfeld, International Economics, (Addison Welsey, 2003).

${ }^{19}$ Jeffrey Frieden, 'Invested Interests: The Politics of National Economic Policies in a World of Global Finance', International Organization, Vol. 45, No. 4 (1991), pp. 425-451.

${ }^{20}$ Oatley, ‘How Constraining is Capital mobility?’, p. 1004.

${ }^{21}$ Cohen, 'Phoenix Arisen', p. 286.

${ }^{22}$ Louis Pauly \& John Goodman, ‘The Obsolescence of Capital Controls? Economic Management in the Age of Global Markets', World Politics, Vol. 46, No. (1993), pp. 50-82; Benjamin Cohen, “'Money in a Globalized World' in N. woods (Ed), The Political Economy of Globalization, (Palgrave, 2000), pp. 79-80. 
${ }^{23}$ Some empirical dissent from the orthodoxy asserting the enduring 'policy space' for (particularly left) governments despite the constraining conditions highlighted by the capital mobility hypothesis relies primarily on data from the 1970s, 1980s and early 1990s - i.e. largely before financial deregulation had reached its zenith (Oatley, 'How Constraining is Capital mobility?', Garrett, Partisan Politics in a Global Economy). Whilst understandable, this may understate the nature of constraint under deregulated conditions.

${ }^{24}$ Swank, Global Capital, Political Institutions, and Policy Change in Developed Welfare States \& Mosley, Global Capital and National Governments.

${ }^{25}$ Oatley, ‘How Constraining is Capital mobility?’, p. 1006.

${ }^{26}$ Gerald Epstein \& Herbert Gintis, (1995) ‘International Capital Markets and National Economic Policy', Review of International Political Economy, Vol. 2, No. 4 (1995), pp. 693-718.

${ }^{27}$ Martin Feldstein \& Charles Horioka, 'Domestic Savings and International Capital Flows', The Economic Journal, Vol. 90, (June 1980), pp. 314-329.

${ }^{28}$ Gerald Epstein, 'International Capital Mobility and the Scope for National Economic Management' in D. Drache \& R. Boyer (Eds), States Against Markets : The Limits of Globalization, (Routledge, 1996), pp. 211-226.

${ }^{29}$ Matthew Watson, 'Rethinking Capital Mobility: Re-regulating Financial Markets', New Political Economy, Vol. 4, No. 1 (1999), pp. 55-75.

${ }^{30}$ Sinclair, 'International Capital Mobility: An Endogenous Approach’, p. 99.

${ }^{31}$ Andrews, ‘Capital Mobility and State Autonomy’.

${ }^{32}$ Sinclair, ‘International Capital Mobility: An Endogenous Approach’, p. 101.

${ }^{33}$ Kenneth Dyson, 'EMU as Europeanization: Convergence, Diversity and Contingency’, Journal of

Common Market Studies, Vol. 38, No. 4 (2000), pp. 645-66 \& 'Introduction: EMU as Integration, Europeanization, and Convergence’ in K. Dyson (Ed), The European State in the Euro-Zone, (Oxford University Press, 2002), pp. 1-30.

${ }^{34}$ Elie Cohen, La Tentation Hexagonale, (Fayard, 1996), pp. 343-347.

${ }^{35}$ David Howarth, “The French State in the Euro Zone', in K. Dyson (Ed), The European State in the Euro-Zone, (Oxford University Press, 2002), pp. 147-9

${ }^{36}$ Dyson, 'EMU as Europeanization', p. 647. 
${ }^{37}$ Mosley, 'Room To Move’, \& Global Capital and National Governments. See also Balls, ‘Open Macroeconomics'.

${ }^{38}$ Mosley, 'Room to Move’, p. 759.

${ }^{39}$ Indeed, Mosley’s analysis indicates that a hypothesised shift from a deficit of 10 percent to a balanced budget within an advanced capitalist economy would, 'holding all other indicators equal, only lead to a 0.5 percent improvement in the cost of government borrowing. See 'Room to Move’, p. 759.

${ }^{40}$ Randall Germain, The International Organisation of Credit, (Cambridge University Press, 1997).

${ }^{41}$ M.S. Kumar, B. Tiamur, J. Decressin, C. Faulkner-MacDonagh, T. Feyziogulu, Deflation:

Determinants, Risks, and Policy Options, IMF Occasional Paper, No. 221 (2003).

${ }^{42}$ See, for example, John Gray, False Dawn (Granta, 1998).

${ }^{43}$ Germain, The International Organisation of Credit.

${ }^{44}$ Timothy Sinclair, ‘Global Monitor: Bond Rating Agencies’ New Political Economy vol. 8 no. 1, pp. 147 \& 148. See also Sinclair, ‘International Capital Mobility: An Endogenous Approach’, p. 102 \& Sinclair, 'Deficit Discourse: the Social Construction of Fiscal Rectitude’.

${ }^{45}$ Sinclair, 'Deficit Discourse: the Social Construction of Fiscal Rectitude’, p. 195.

${ }^{46}$ The last change to long-term sovereign bond rates for France was an upgrade to AAA on February $25^{\text {th }} 1992$, for the UK an upgrade to AAA on $28^{\text {th }}$ April 1993. See http://www.moodyseurope.com.

${ }^{47}$ Kenneth Dyson \& Kevin Featherstone, The Road to Maastricht: Negotiating Economic and Monetary Union, (Oxford University Press, 1999); Barry Eichengreen \& Jeffrey Frieden, (Eds.) The Political Economy of European Monetary Union, (Westview Press, 1994).

${ }^{48}$ Dyson, 'Introduction: EMU as Integration, Europeanization, and Convergence', pp. 7 \& 16; Dyson, 'EMU as Europeanization', p. 646; Dyson \& Featherstone, The Road to Maastricht: Negotiating Economic and Monetary Union, pp. 777-9

${ }^{49}$ Mosley, 'Room To Move', p. 752 \& Global Capital and National Governments, pp. 66-9. Indeed, this yardstick became widely applied to non-EU states even though participants themselves recognised there was no good or logical reason for plucking 3 per cent out of the sky. This is no doubt largely because, shaped by central bankers and finance ministry technocrats, these criteria reflected a political economic paradigm that the two sets of actors shared.

${ }^{50}$ Dyson, ‘EMU as Europeanization’, p. 648. 
${ }^{51}$ Mosley, 'Room To Move', p. 753.

${ }^{52}$ Mosley, 'Room To Move’, p. 753.

${ }^{53}$ There is much debate in the economics literature on the existence/scale of these effects. See for example Barry Eichengreen and Charles Wyplosz, 'The Stability Pact: More than a Minor Nuisance?' Economic Policy, Vol. 26 (1998), pp. 67-113; Sylvester Eijffinger and Jakob Hahn, European Monetary and Fiscal Policy (Oxford University Press, 2000), pp. 81-87.

${ }^{54}$ Malcolm Crawford, One Money for Europe? (Macmillan, 1996), pp. 304-7.

${ }^{55}$ The core commitment of the Stability and Growth Pact, is to fiscal discipline and stabilization. It commits states to the '.. medium-term objective of budgetary positions close to balance or in surplus...' which '... will allow Member States to deal with the normal cyclical fluctuations while keeping the government deficit within the 3 per cent [of GDP] reference value'. Formally, the Pact consists of three elements:- preventive elements which through regular surveillance aim at preventing budget deficits going above the 3 per cent of GDP; dissuasive elements which in the event of the 3 per cent level being breached, require Member States to take immediate corrective action and, if necessary, allow for the imposition of sanctions. Lastly, it involves a political commitment by all parties involved in the Pact (Commission, Member States, Council) to the full and timely implementation of the budget surveillance process. European Commission, The European Economy: Public finances in EMU, (European Commission, 2000), pp. 45-7.

${ }^{56}$ Marco Buti, Sylvester Eijffinger, and Daniele Franco, 'Revisiting the EU’s Stability Pact: A Pragmatic Way Forward', Oxford Review of Economic Policy, Vol. 19, No. 1 (2003), pp. 100-111.

${ }^{57}$ Catherine Mathieu and Henri Sterdyniak, 'Réformer le Pacte de Stabilité: L’Etat du Débat', Revue de l'OFCE, no. 84 (2003), p. 148.

${ }^{58}$ The debt ratio has proved a much less problematic issue, helped by lower interests rates.

${ }^{59}$ Mathieu and Sterdyniak, 'Réformer le Pacte de Stabilité: L’Etat du Débat', pp. 150-1.

${ }^{60}$ Marco Buti, Daniele Franco, and Hedwig Ongena, Budgetary Policies During Recessions (EU, 1997).

${ }^{61}$ Christopher Allsopp, and Michael Artis, ‘The Assessment: EMU Four Years On’, Oxford Review of Economic Policy, Vol. 19, No. 1 (2003), pp. 12-16. 
${ }^{62}$ Dyson, 'Introduction: EMU as Integration, Europeanization, and Convergence’, and 'EMU as Europeanization'.

${ }^{63}$ Romano Prodi, President of the Commission called the SGP ‘stupid', above all because it restricted counter-cyclical policy at a time when there appeared no threat of inflation, which was fundamentally the problem the rules were supposed to combat. Financial Times 'Prodi says euro rules are 'stupid', 18 October 2002.

${ }^{64}$ Kenneth Dyson, 'Benign or Malevolent Leviathan? Social Democratic Governments in a NeoLiberal Euro Area', Political Quarterly, Vol. 70, No. 2, p.198.

${ }^{65}$ Mathieu and Sterdyniak, 'Réformer le Pacte de Stabilité: L’Etat du Débat’, p. 156.

${ }^{66}$ Oatley, 'How Constraining is Capital mobility?’, p. 1004.

${ }^{67}$ Ben Clift, French Socialism in a Global Era: The Political Economy of the New Social Democracy in France, (Continuum, 2003), pp. 132-57 \& 185-95; and Clift, 'The Changing Political Economy of France: Dirigisme under Duress’, pp. 179-184.

${ }^{68}$ This was a historically significant shift in French macro-policy making. Since the Second World War, France avoided ever having a public spending deficit greater than 3 per cent.

${ }^{69}$ France alone amongst EMU participant countries officially failed to respect the 3 per cent deficit figure for its 1997 budget, although other authoritative sources indicated that France had met the 3 per cent deficit criterion. Gael Dupont, 'La politique économique’ in OFCE, L'économie Française 2000, (La Découverte, 2000), p. 65.

${ }^{70}$ Dupont, ‘La politique économique’, p. 65.

${ }^{71}$ Public spending accelerated in 1999 (+2.4 per cent in volume, compared with average of 1.2 per cent 93-7). See Gael Dupont, 'La politique économique’ in OFCE, L'économie Française 2001, (La Découverte, 2001), pp. 63-5. On the redistribution front, the Solidarity Tax on Wealth (ISF) was made more progressive. It was increased in the 1998 budget, its coverage was extended to close a number of loopholes, and a new band introduced in the 1999 budget. See Gérard Cornilleau \& Henri Sterdyniak, ‘La politique économique’ in OFCE, L'économie Française 1999, (La Découverte, 1999), p. 63.; Ministère de L’Economie, des Finances, et du Budget. 'Projet de loi de finances pour 2002' Les Notes Bleues Hors-série, (September 2001), p. 20; Clift, French Socialism in a Global Era, pp. 158-166.

${ }^{72}$ Ministère de L’Economie, des Finances, et du Budget, 'Projet de loi de finances pour 2002', p. 11. 
${ }^{73}$ In November 2002 the Commission, while re-affirming the medium-term balanced budget rule, did recognise some of the difficulties of the SGP. They suggested inter alia that countries should not pursue pro-cyclical policies during periods of growth (so reducing their room for manoeuvre in the downswing). Ian Begg, Dermot Hodson and Imelda Maher, 'Economic Policy Co-ordination in the EU’, National Institute Economic Review, No. 183 (2003), pp.74-6.

${ }^{74}$ In March 2000, a 10 per cent income tax cut was introduced for 5m lower earners, and 650,000 particularly low earners were exempted from taxation altogether (Financial Times, 23 March 2000). In September 2000, income tax was further reduced (Libération, 31 August 2000). Whilst this disproportionately favoured low and non-earners, the reorganization of income tax 2000-2003 included a reduction in income tax rates for all income bands.

${ }^{75}$ Debt servicing costs did remain significant - 14 per cent of general budget spending in 2000.

${ }^{76}$ Dupont, ‘La politique économique’, in OFCE, L’économie Française 2000, (La Découverte, 2000), p. 63. It should be noted that, for all the talk of eroding autonomy, capital mobility offers opportunity as well as constraint. International capital markets, which advanced industrialised countries 'seem to be able to access ... with relative impunity', offer a means of funding current account deficits. This, combined with lower interest rates attendant upon the improved creditworthiness which comes with membership of the Euro, has relaxed current account constraints to a very considerable degree. Erik Jones, 'Liberalized Capital Markets, State Autonomy, and EMU’ European Journal of Political Research, Vol. 42, No. 2 (2003), pp. 212-3 \& 218-19.

${ }^{77}$ Ben Clift, 'The French Model of Capitalism: Still Exceptional?’ in J. Perraton \& B. Clift (Eds.), Where Are National Capitalisms Now? (Palgrave, 2004), pp. 91-110, \& Clift, 'The Changing Political Economy of France: Dirigisme under Duress’, pp. 173-196.

${ }^{78}$ Ministère de l’Economie, des Finances, et de l’Industrie 'Programme de stabilité 2005-2007'. http://www.minefi.gouv.fr/

${ }^{79}$ OFCE, ‘Méprise sur la reprise: Perspectives pour L’Economie Française 2004-2005’ Lettre de l'OFCE, No. 248 (2004), pp. 6-8.

${ }^{80}$ Odile Chagny, Gael Dupont, Paola Monperrus-Veroni, ‘Politiques Budgétaires en Europe: L’Heure de vérité', La Lettre de L'OFCE, No. 234 (2003), pp. 3-4. 
${ }^{81}$ Pedro Solbes, 'Budgetary Challenges in the euro area', Communication, SEC 1009/3, 24 September 2002.

${ }^{82}$ Deficit forecasts for 2002 and 2003 had to be significantly revised upwards given a less favourable economic conjuncture. The government told the Commission its 2002 deficit was 3.04 per cent of GDP, and claimed that - if the figure were rounded down - this meant the French Government was not liable for excessive deficit procedures. Le Monde, 'Querelle de chiffres entre Bruxelles et Paris autour du déficit', 3 March 2003. The figure, however, was contested - not least by the Commission itself. Authoritative sources calculated the deficit at 3.1 per cent of GDP (see e.g. OFCE, 'France: Les Illusions Perdus', Revue de l'OFCE, No. 85 (2003), p. 188.

${ }^{83}$ Jérome Créel, Gael Dupont, Jacques Le Cacheux, Henri Sterdyniak and Xavier Timbeau, 'Budget 2003: Le pécheur non repenti', La Lettre de L'OFCE, No. 224 (2002), pp. 1-4; Mathieu and Sterdyniak, ‘Réformer le Pacte de Stabilité: L’Etat du Débat’, pp. 154 \& 159.

${ }^{84}$ Overall, the boost or impetus to the economy provided by budgetary policy for 2002 has been calculated at 1.1 per cent of GDP. See Chagny, Dupont \& Monperrus-Veroni, 'Politiques Budgétaires en Europe: L’Heure de vérité', pp. 1 \& 3, and OFCE, ‘France: Les Illusions’, P. 159.

${ }^{85}$ Clift, French Socialism in a Global Era, p. 160.

${ }^{86}$ Le Monde, 'Impôts: la quadrature de la baisse. Chirac veut 3 pour cent, Raffarin environ 1 pour cent. Alors que le déficit public est à la dérive.’ 8 August 2003.

${ }^{87}$ Le Monde, 1 December 2003.

${ }^{88}$ Banque de France Bulletin Digest, Nos. 121-123 (January- March 2004).

${ }^{89}$ Le Monde, 27 November 2003.

${ }^{90}$ France in 2003 saw its growth rate dip to the lowest rate since the recession of 1993. This was in part due to the competitive shock of the appreciation of the Euro vis-à-vis the dollar between 2001 and 2004.

${ }^{91}$ OFCE, ‘Méprise sur la reprise: Perspectives pour L’Economie Française 2004-2005’, p. 8.

${ }^{92}$ Chagny, Dupont \& Monperrus-Veroni, ‘Politiques Budgétaires en Europe: L’Heure de vérité’, p. 4.

${ }^{93}$ Chagny, Dupont \& Monperrus-Veroni, 'Politiques Budgétaires en Europe: L’Heure de vérité’, p. 2;

Créel, Dupont, Le Cacheux, Sterdyniak, and Timbeau, ‘Budget 2003: Le pécheur non repenti’; OFCE, 'Méprise sur la reprise: Perspectives pour L’Economie Française 2004-2005’. 
${ }^{94}$ Teresa Dabán, Enrica Detragiache, Gabriel di Bella, Gian Maria Milesi-Ferretti, and Steven Symansky, 'Rules-Based Fiscal Policy in France, Germany, Italy, and Spain’ International Monetary Fund, Occasional Paper, No. 225 (2003). http://www.imf.org/external/pubs/nft/op/225/index.htm ${ }^{95}$ IMF 'France: 2003 Article IV Consultation Concluding Statement of the Mission, June 30, 2003, http://www.imf.org/external/np/ms/2003/063003.htm Accessed 15 ${ }^{\text {th }}$ August 2003. Echoing the SGP, the IMF urges 'a small structural budget surplus within the next five years' and that the French State should 'run such a surplus for as long as needed to reduce the public debt-to-GDP ratio to deal with the costs of ageing and to create room for a desirable reduction in the tax burden'.

${ }^{96}$ OFCE, ‘Méprise sur la reprise: Perspectives pour L’Economie Française 2004-2005’, p. 8.

${ }^{97}$ Phillip Stephens, Politics and the Pound, (Macmillan, 1996), pp. 269-70.

98 Treasury, 'Budget 2000: Prudent for a Purpose', (HMSO, 2000), p. 215.

${ }^{99}$ OECD, (1996), pp.35-7.

${ }^{100}$ Stephens, Politics and the Pound, p. 293.

101 Treasury, 'Budget 2000: Prudent for a Purpose', p. 215.

102 Treasury, Budget Report, (HMSO, 2003), p. 20.

${ }^{103}$ Balls, 'Open Macroeconomics in an Open Economy’, p.120.

${ }^{104}$ Balls, 'Open Macroeconomics in an Open Economy’, p.122.

105 Stephens, Politics and the Pound, pp. 278-81.

${ }^{106}$ Stephen Nickell, 'The Assessment: The Economic Record of the Labour Government Since 1997’, Oxford Review of Economic Policy, Vol. 18, No. 2 (2002), pp. 109-110.

${ }^{107}$ Treasury, Code for Fiscal Stability, (HMSO, 1998); Gordon Brown, 'Mansion House Speech', Treasury Press Release, 11 June 1998.

${ }^{108}$ Tom Clark, Andrew Dilnot, Alissa Goodman and Michael Myck, 'Taxes and Transfers 1997-2001’, Oxford Review of Economic Policy, Vol. 18, No. 2 (2002), pp. 187-201; Catherine Mathieu, 'Politique Economique: La Clé Anglaise’ La Lettre de L’OFCE no. 233 (2003), p. 2.

${ }^{109}$ Mathieu and Sterdyniak, 'Réformer le Pacte de Stabilité: L’Etat du Débat', p. 151.

${ }^{110}$ William Keegan, The Prudence of Mr Gordon Brown, (Wiley, 2003), p. 332.

111 Treasury, Budget Report, (HMSO, 2003), Chapter 2, p. 9.

112 Treasury, Budget Report, (HMSO, 2003), Chapter 2, pp. 9-12. 
${ }^{113}$ Treasury, Financial Statement and Budget Report, (HMSO, 2004), p. 246.

${ }^{114}$ Treasury, Budget Report, (HMSO, 2003), p. 20.

${ }^{115}$ Treasury, Financial Statement and Budget Report, (HMSO, 2004), p. 244.

${ }^{116}$ National Institute, ‘Economic Overview’ National Institute Economic Review, No. 185 (2003), pp.

3-4.

${ }^{117}$ Mathieu, 'Politique Economique: La Clé Anglaise’, p. 2.

${ }^{118}$ Keegan, The Prudence of Mr Gordon Brown, p. 275.

${ }^{119}$ The Economist, 20 March 2004.

${ }^{120}$ (IMF 2004 pp.10-14)

${ }^{121}$ Balls, ‘Open Macroeconomics in an Open Economy’, pp. 113-132.

${ }^{122}$ Keegan, The Prudence of Mr Gordon Brown, p. 17.

${ }^{123}$ Treasury, Financial Statement and Budget Report, (HMSO, 2004).

${ }^{124}$ Dyson, 'Introduction: EMU as Integration, Europeanization, and Convergence’, p. 7.

${ }^{125}$ In fact the two major agencies have shown some differences of opinion, with Moody’s assigning all EMU countries an AAA rating, but Standard and Poor’s downgrading Belgium, Ireland, Italy, Spain, Finland and Portugal to varying degrees Temperton 1998, pp.273-5; Arnold 1999). But the downgradings have been quite small, and none of these countries seems to have suffered in their ability to borrow from these less than triple A ratings. 